\title{
Magnesium Octa[(4'-benzo-15-crown-5)oxy]phthalocyanine in Phosphate Buffer: Supramolecular Organization, Cytotoxicity and Accumulation/Localization in Tumor Cells of HeLa
}

\author{
M. A. Lapshina, ${ }^{a}{ }^{\mathrm{a} @ 1}$ S. I. Norko, ${ }^{\mathrm{b}}$ V. E. Baulin, ${ }^{\mathrm{c}, \mathrm{d}}$ A. A. Terentiev, ${ }^{\mathrm{a}, \mathrm{b}, \mathrm{e}}$ A. Yu. Tsivadze, $^{\mathrm{c}}$ \\ N. F. Goldshleger ${ }^{\circledR 2}$ \\ anstitute of Problems of Chemical Physics RAS, 142432 Chernogolovka, Russia \\ ${ }^{\mathrm{b}}$ Lomonosov Moscow State University, 119991 Moscow, Russia \\ ${ }^{\mathrm{c}}$ Frumkin Institute of Physical Chemistry and Electrochemistry RAS, 119071 Moscow, Russia \\ dinstitute of Physiologically Active Compounds RAS, 142432 Chernogolovka, Russia \\ ${ }^{\mathrm{e}}$ Moscow Region State University, 105005 Moscow, Russia \\ ${ }^{\circledR 1}$ Corresponding author E-mail: lapshina@icp.ac.ru \\ ${ }^{\circledR 2}$ Corresponding author E-mail:nfgold@icp.ac.ru
}

\begin{abstract}
For the first time, magnesium octa[(4'-benzo-15-crown-5)oxy]phthalocyanine $\left(\mathrm{Mgcr}_{8} \mathrm{Pc}_{\mathrm{C}}\right)$ was explored as a potential PDT agent. Presence of crown-containing fragments in the periphery of the tetrapyrrole macrocycle makes the compound soluble in water. Solutions of $\mathrm{Mgcr}_{8} \mathrm{Pc}_{\mathrm{C}}$ in water and in phosphate buffer (PBS) are stable for a long time. Modification of $\mathrm{Mgcr}_{8} \mathrm{Pc}_{\mathrm{C}}$ solutions in PBS with sodium deoxycholate led to partial monomerization of $M g c{ }_{8} P c$ and hence to formation of a fluorescent species. The cytotoxicity of $\mathrm{Mgcr}_{8} \mathrm{Pc}_{\mathrm{c}}$ was determined with respect to HeLa cells and its accumulation/localization in the cells was studied by fluorescence microscopy. The increase in signal intensity indicates the accumulation of $\mathrm{Mgcr}_{8} \mathrm{Pc}$ in HeLa cells over time. The cell morphology was found to remain practically intact when subjected to $\mathrm{Mgcr}_{8} \mathrm{Pc}$ at concentration of $5.00 \mu \mathrm{M}$ for $24 \mathrm{~h}$. The results obtained allow us to continue the study of this interesting class of compounds.
\end{abstract}

Keywords: Phthalocyanine, crown ether conjugates, solubility in water, spectral properties, supramolecular organization, sodium deoxycholate, HeLa cells, cytotoxicity, accumulation, localization, fluorescence microscopy.

\section{Окта[(4'-бензо-15-краун-5)окси]фталоцианинат магния в фосфатном буфере: супрамолекулярная организация, цитоксичность, накопление и локализация в опухолевых клетках HeLa}

\author{
M. А. Лапшина, ${ }^{\mathrm{a}, \mathrm{e} @ 1}$ C. И. Норко, ${ }^{\text {b }}$ B. Е. Баулин, ${ }^{\mathrm{c}, \mathrm{d}}$ A. А. Терентьев, ${ }^{\mathrm{a}, \mathrm{b}, \mathrm{e}}$ \\ А. Ю. Цивалзе, ${ }^{\text {c }}$ Н. Ф. Гольдшлегер ${ }^{\mathrm{a}} 2$ \\ а Институт проблем химической физики РАН, 142432 Черноголовка, Россия \\ ' Московский государственньій университет имени М.В. Ломоносова, 119991 Москва, Россия \\ ' Институт физической химии и электрохимии им. А.Н. Фрумкина РАН, 11999 Москва, Россия \\ ${ }^{\mathrm{d}}$ Институт физиологически активных вещееств РАН, 142432 Черноголовка, Россия \\ 'Московский государственный областной университет, 105005 Москва, Россия \\ ${ }^{\circledR 1}$ E-mail: lapshina@icp.ac.ru \\ ${ }^{@ 2}$ E-mail:nfgold@icp.ac.ru
}

Окта[(4'-бензо-15-краун-5)окси]фталоцианинат магния $\left(\mathrm{Mgcr}_{8} \mathrm{Pc}\right)$ в фосфатном буфере впервые исследуется как потенцииальный ФДТ-агент. Присутствие краун-содержащих фрагментов на периферии тетрапиррольного макроиикла обеспечивает растворимость соединения в водной среде. Paстворы Mgcr $P$ с в воде и фосфат- 
ном буфере стабильны в течение длительного времени в обычных условиях. Введение дезоксихолата натрия приводило к частичной мономеризации и формированию флуоресцентно-активных частии, соответственно. Определена ичитотоксичность Mgcr $P$ P и показано его накопление и локализация в клетках HeLa. Cогласно флуоресцентной микроскопии, морфология клеток не изменяется после 24-х часового действия $\mathrm{Mgcr}_{8} P c$ в дозе 5.00 мкM.

Ключевые слова: Фталоцианин, конъюгаты с краун-эфирами, растворимость в воде, спектральные свойства, супрамолекулярная организация, дезоксихолат натрия, опухолевые клетки HeLa, цитотоксичность, накопление, локализация, флуоресцентная микроскопия.

\section{Introduction}

Phthalocyanines $(\mathrm{Pc})$ and their supramolecular aggregates are applied in molecular electronics, chemical sensors, catalysis, biology, and medicine, including photodynamic therapy (PDT). ${ }^{[1-3]}$ PDT, which is an actively developing field of research for the treatment of a variety of cancers, is based on the capability of photosensitizer (PS) to accumulate preferentially in the tumor and by a precise illumination to form highly reactive oxygen species, which result in cytotoxic reactions in the cells. ${ }^{[4]}$

Along with chemical stability, phthalocyanines exhibit absorption bands with intense $\pi-\pi^{*}$ transitions in the range of $650-850 \mathrm{~nm}\left(\varepsilon \geq 10^{5} \mathrm{M}^{-1} \mathrm{~cm}^{-1}\right)$, low toxicity, and high quantum yield of the triplet state, which makes Pc a feasible PS in fluorescent diagnostics and PDT of malignant neoplasms. ${ }^{[5-8]}$ A comparison of some Pcs as photosensitizers has already been made in vitro (e.g. see ${ }^{[9]}$ and references therein). Complexes containing $\mathrm{Zn}^{2+}, \mathrm{Al}^{3+}, \mathrm{Ga}^{3+}, \mathrm{Mg}^{2+}$, etc. in the centre of the macrocycle seem to be most suitable for PDT. For instance, hydroxyaluminum phthalocyanine trisulfonate (Photosens ${ }^{[7]}$ has been approved for clinical PDT in Russia. In order to generate reactive oxygen species (largely singlet oxygen), $\mathrm{Pc}$ is to be in its monomer state in solution. However, this is difficult to achieve in view of (a) aggregation of Pc molecules in polar media and (b) poor solubility of phthalocyanines in water.

In this work, magnesium octa[(4'-benzo-15-crown5)-oxy]phthalocyanine $\left(\mathrm{Mgcr}_{8} \mathrm{Pc}\right.$, Figure 1) is explored as a potential PDT agent. The study includes (a) the determination of cytotoxicity of $\mathrm{Mgcr}_{8} \mathrm{Pc}$ with respect to HeLa cells and (b) its accumulation/localization in tumor cells HeLa in vitro. Considerable attention is also paid to the state of $\mathrm{Mgcr}_{8} \mathrm{Pc}$ in the cell growth medium as well as supramolecular organization of Pc in microheterogeneous media based on anionic surfactants, including biocompatible sodium deoxycholate, in phosphate buffer ( $\mathrm{pH}$ 7.4). The presence of the crown fragments improves the solubility of complexes and promotes the self-assembling of Pc with a guest cation, ${ }^{[10-12]}$ as well as opens up a way to preparation of materials with remarkable physicochemical characteristics. $^{[13,14]}$

\section{Experimental}

\section{General}

The synthesis of magnesium octa[(4'-benzo-15-crown-5) oxy]phthalocyanine $\left(\mathrm{Mgcr}_{8} \mathrm{Pc}\right)$ was carried out as described elsewhere. ${ }^{[15]}$ Commercially available sodium dodecyl sulphate (SDS), sodium deoxycholate (SDC) (Aldrich, $98 \%$ ) and $\mathrm{NaCl}$ (extra-pure grade) were used without additional purification. Salts used in preparation of phosphate buffer saline with $\mathrm{pH} 7.4$ (hereinafter PBS) also were of extra pure grade; according to protocol, the $\mathrm{NaCl}, \mathrm{KCl}, \mathrm{Na}_{2} \mathrm{HPO}_{4}$, and $\mathrm{KH}_{2} \mathrm{PO}_{4}$ concentrations were $137,2.7,10$ and $1.76 \mathrm{mM}$, respectively. Solutions were prepared by using double distilled or deionized water. The concentration of the $\mathrm{Mgcr}_{8} \mathrm{Pc}$ stock solution was equal to $594 \mu \mathrm{M}$. All solutions were stored in the dark.

To study the effect of salts, equal number of $\mathrm{mL}$ of the $\mathrm{Mgcr}_{8} \mathrm{Pc} / \mathrm{SDC} / \mathrm{NaCl}$ solution $\left(\left[\mathrm{Mgcr}_{8} \mathrm{Pc}\right]=9.3 \cdot 10^{-6} \quad \mathrm{M}\right.$, $[\mathrm{SDC}]=0.0175 \mathrm{M},[\mathrm{NaCl}]=0.139 \mathrm{M})$ was placed in two identical cuvettes. In one of them we added a dry sample of $\mathrm{KCl}$ : total
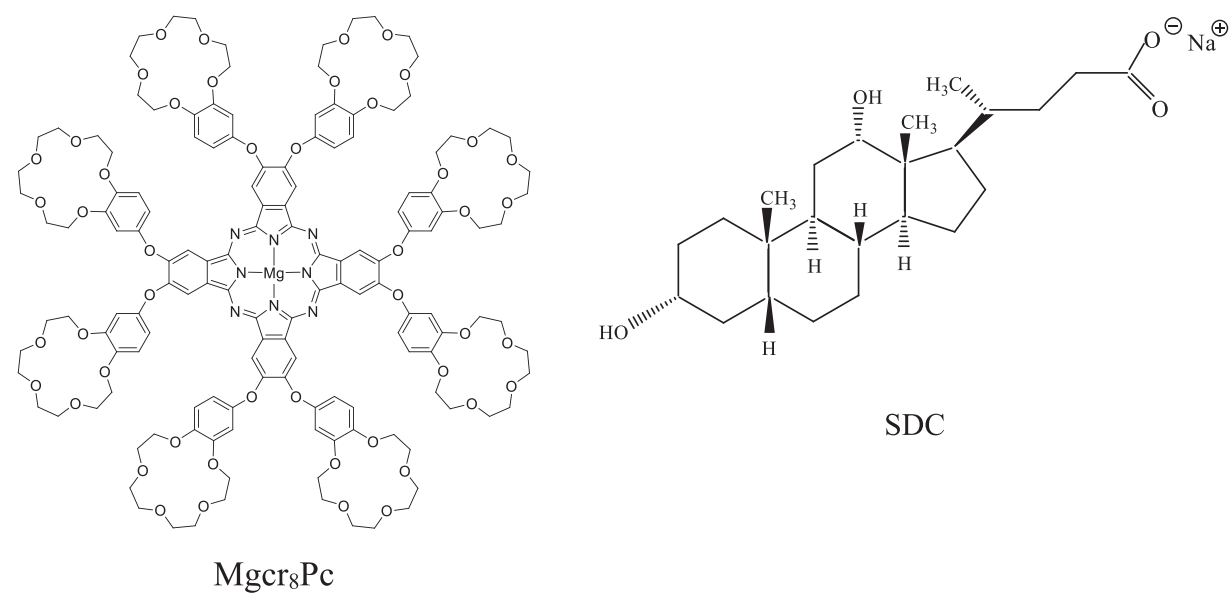

SDC

Figure 1. Chemical structure of magnesium octa[(4'-benzo-15-crown-5)-oxy]phthalocyanine and sodium deoxycholate. 
concentration of salts $(\mathrm{NaCl}+\mathrm{KCl})$ in solution under study was equal to $0.16 \mathrm{M}$. The $\mathrm{NaCl}$ sample was also introduced in second cuvette. In both cases, the ionic strength of the solution and the concentrations of $\mathrm{Mgcr}_{8} \mathrm{Pc}$ and SDC did not change. The absorption spectra were recorded in time.

\section{Determination of $\mathrm{MgCr}_{8} \mathrm{Pc}$ Absorbed}

HeLa (human cervical adenocarcinoma) cells were incubated in Eagle MEM medium (EMEM, hereinafter merely "medium") modified by the addition of $\mathrm{Mgcr}_{8} \mathrm{Pc}$ solution in PBS. In $24 \mathrm{~h}$, the solution was poured out and the cells were washed several times with $2 \mathrm{~mL}$ portions of PBS. The absorption spectra of the collected $\mathrm{Mgcr}_{8} \mathrm{Pc}$ were close to those of Pc aggregates and $\mathrm{Pc}$ in reference to $\mathrm{Mgcr}_{8} \mathrm{Pc} /$ medium/PBS solutions. The concentration of $\mathrm{Mgcr}_{8} \mathrm{Pc}$ was determined spectrophotometrically. The amount of $\mathrm{Mgcr}_{8} \mathrm{Pc}$ absorbed by the cells $\left(\left[\mathrm{Mgcr}_{8} \mathrm{Pc}\right]_{\mathrm{ab}}\right)$ was calculated from the difference between the initial concentration of $\mathrm{Pc}$ $\left(\left[\mathrm{Mgcr}_{8} \mathrm{Pc}\right]_{0}\right)$ and the amount of Pc collected after the incubation stage $\left(\left[\mathrm{Mgcr}_{8} \mathrm{Pc}\right]_{\mathrm{fr}}\right)$ :

$$
\begin{array}{ccc}
{\left[\mathrm{Mgcr}_{8} \mathrm{Pc}\right]_{0}, \mu \mathrm{M}} & {\left[\mathrm{Mgcr}_{8} \mathrm{Pc}\right]_{\mathrm{fr}} \mu \mathrm{M}} & {\left[\mathrm{Mgcr}_{8} \mathrm{Pc}\right]_{\mathrm{ab}}, \%} \\
20 & 14 & \sim 30 \\
10 & 6.08 & \sim 40
\end{array}
$$

For $\left[\mathrm{Mgcr}_{8} \mathrm{Pc}\right] \leq 5 \mu \mathrm{M}$, washing solutions contained practically no Pc.

Optical absorption spectra were recorded with a Specord M-40 spectrophotometer by using 1-, 2-, and 10-mm quartz cells. In some cases, the spectra were deconvoluted into components.

Fluorescence spectra of $\mathrm{Mgcr}_{8} \mathrm{Pc} / \mathrm{SDC}$ in $\mathrm{PBS}$ solutions stored for $24 \mathrm{~h}$ were recorded with a PerkinElmer LS55 spectrofluorimeter at room temperature. The slit width was $10 \mathrm{~nm}$; the wavelength of excitation was $614 \mathrm{~nm}$.

\section{Biological Experiments}

Cell culture. HeLa cells were obtained from the Russian collection of cell cultures of vertebrates. The tumor cells were grown in EMEM medium (PanEco, Russia) containing $10 \%$ embrionic whey (Biowest, France), penicillin (50 units $/ \mathrm{mL}$ ), and streptomy$\operatorname{cin}(50 \mathrm{mg} / \mathrm{ml})$ at $37^{\circ} \mathrm{C}$ in a $5 \% \mathrm{CO}_{2}$ atmosphere.

MTT test. The influence of $\mathrm{Mgcr}_{8} \mathrm{Pc}$ on cell growth and viability was studied upon their staining with 3-(4,5-dimethyl-2-thiazolyl)-2,5-diphenyl-2 $\mathrm{H}$-tetrazolium bromide (MTT, Sigma-Aldrich). ${ }^{[16-18]}$ The cells were dissipated in 96-well plates in the amount of $5 \cdot 10^{3}$ cells $/ 100 \mu \mathrm{L}$ for each well. In order to determine the cytotoxity of $\mathrm{Mgcr}_{8} \mathrm{Pc}$, its solution in PBS $(0.5-25 \mu \mathrm{M})$ was added to the incubation medium. The incubation period in the presence of Pc was $24 \mathrm{~h}$. Dark toxicity of $\mathrm{Mgcr}_{8} \mathrm{Pc}$ towards HeLa cells was studied both with and without rinsing the samples with PBS. In the first case, the cells were washed twice with $50 \mu \mathrm{L}$ of buffer PBS before applying MTT dye. After this, $0.5 \mathrm{mg} / \mathrm{mL}$ MTT was added and the plate was held at $37{ }^{\circ} \mathrm{C}$ in a $5 \% \mathrm{CO}_{2}$ atmosphere for $3 \mathrm{~h}$. Then the incubation medium was removed and the formed formazan crystals were dissolved in DMSO for 10 min. The MTT assay was established at $570 \mathrm{~nm}$ (Tecan SPARK $10 \mathrm{M}$ device). Cells' viability was estimated as the percentage of MTT stained control cells. The $\mathrm{IC}_{50}$ dose (concentration of a compound that reduces MTT staining by $50 \%$ ) was found using the median effect analysis. Each experiment was repeated three times.

Fluorescence Microscopy. The cells grown on cover glasses (450 000 in each) were incubated with $\mathrm{Mgcr}_{8} \mathrm{Pc}$ added in concentrations of $5 \mu \mathrm{M}$ for 3 or $24 \mathrm{~h}$, respectively. After incubation, the remaining $\mathrm{Mgcr}_{8} \mathrm{Pc}$ was washed out with PBS. Then the cells were held in $4 \%$ paraformaldehyde solution in PBS at r.t. for $30 \mathrm{~min}$, in $0.5 \%$ solution of Triton $\mathrm{X}-100$ for $10 \mathrm{~min}$, stained in DAPI (4',6-diamidino-2-phenylindole-2HCl) solution for $10 \mathrm{~min}$, washed with deionized water and dried at r.t. in the dark. After this, the samples were placed in a drop of fixing fluid Fluoromount (Sigma-Aldrich, Germany) on a cover glass. In the same way, $\mathrm{HeLa}$ cells were also treated with $\mathrm{Mgcr}_{8} \mathrm{Pc}$ without fixing. In this case, the cells grown on cover glasses were placed in a drop of PBS solution just before viewing. Accumulation/localization of $\mathrm{Mgcr}_{8} \mathrm{Pc}$ in fixed and non-fixed tumor cells was explored with an Axio Scope.A1 fluorescence microscope (Carl Zeiss, Germany) using A-Plan 40×/0.65 Ph2, A-Plan 40×/0.65 M27, N-Achroplan $100 \times / 1.25$ Oil M27, and N-Achroplan 100×/1.25 Oil Ph3 M27 objectives and a set of fluorescence filters: Fs 49 DAPI (EX G 365 , EM BP 445/50), Fs 45 HQ TexasRed (EX BP 560/40, and EM BP $630 / 75$ - in combination with a high-resolution digital camera AxioCam MRc 5 and Zen 2012 software (blue edition).

\section{Results and Discussion}

In dichloromethane, the spectra of $\mathrm{Mgcr}_{8} \mathrm{Pc}$ (Figure 1) typically exhibit a strong $\pi-\pi^{*}$ transition at longer wavelengths $\left(\varepsilon \geq 10^{5} \mathrm{M}^{-1} \mathrm{~cm}^{-1}\right)$ and a weaker one at shorter wavelengths ( $Q$-band), and also a weak but broad $B$-band (also called a Soret band) in the UV range (Figure 2a). Such spectral features are typical to monomeric metal phthalocyanine complexes.

\section{Absorption Spectra of $\mathrm{MgCr}_{8} \mathrm{Pc}_{\mathrm{c}}$ in Various Media}

Absorption spectra of $\mathrm{Mgcr}_{8} \mathrm{Pc}$ in water, in $\mathrm{PBS}$ and in EMEM medium are similar. As an example, Figure $2 \mathrm{a}$ presents the absorption spectrum of $\mathrm{Mgcr}_{8} \mathrm{Pc}$ in PBS (curve 2). In contrast to dichloromethane (curve 1), the $Q$-band of $\mathrm{Mgcr}_{8} \mathrm{Pc}$ in aqueous medium is blue-shifted and strongly broadened, which is indicative of the aggregation of phthalocyanine molecules. The blue-shift is caused by the $\pi-\pi$ stacking that is characteristic of dimers, associates and other aggregates. ${ }^{[1]}$ As follows from Figure $2 \mathrm{~b}$, the spectrum of $\mathrm{Mgcr}_{8} \mathrm{Pc}$ in EMEM medium which is similar to that in PBS can be readily deconvoluted into four Gaussian functions. The latter is considered by us only as an indication of the possible variety of particles forming in the solution.

As it is seen in Figure 3a, the addition of anionic $\mathrm{SDC}$ to $\mathrm{Mgcr}_{8} \mathrm{Pc} / \mathrm{PBS}$ solution $([\mathrm{SDC}]>\mathrm{cmc}$ ) causes a red shift of short-wavelength $B$-band and also the narrowing and intensification of the $Q$-band. In the case of $\mathrm{Mgcr}_{8} \mathrm{Pc} /$ $\mathrm{SDC} / \mathrm{NaCl}$ (Figure 3a, spectrum 3 and see $\mathrm{also}^{[19]}$ ), the shape of absorption spectrum and a higher $\varepsilon$ value for the $Q$-band testify a higher concentration of Pc monomer as compared to $\mathrm{Mgcr}_{8} \mathrm{Pc} / \mathrm{SDC} / \mathrm{PBS}$ solution (Figure 3a, spectrum 2), and the $\mathrm{NaCl}$ concentration is close to the physiological value in both systems. It should be also noted that the spectral characteristics such as the shape of spectrum and extinction coefficient (Figure 3a, spectrum 2) remained almost unchanged after the subsequent $\mathrm{NaCl}$ addition to the $\mathrm{Mgcr}_{8} \mathrm{Pc} / \mathrm{SDC} / \mathrm{PBS}$ solution.

The effect of the $\mathrm{Na}^{+}$and $\mathrm{K}^{+}$ions on the spectral characteristics of the micro-heterogeneous system based on $\mathrm{Mgcr}_{8} \mathrm{Pc} / \mathrm{SDC}$ is also shown in Figure 3b. It is seen that the $\mathrm{KCl}$ addition leads to absorption spectrum (Figure 3b, spectrum 2) close to that of the $\mathrm{Mgcr}_{8} \mathrm{Pc} / \mathrm{SDC} / \mathrm{PBS}$ system (Figure 3a, spectrum 2). 

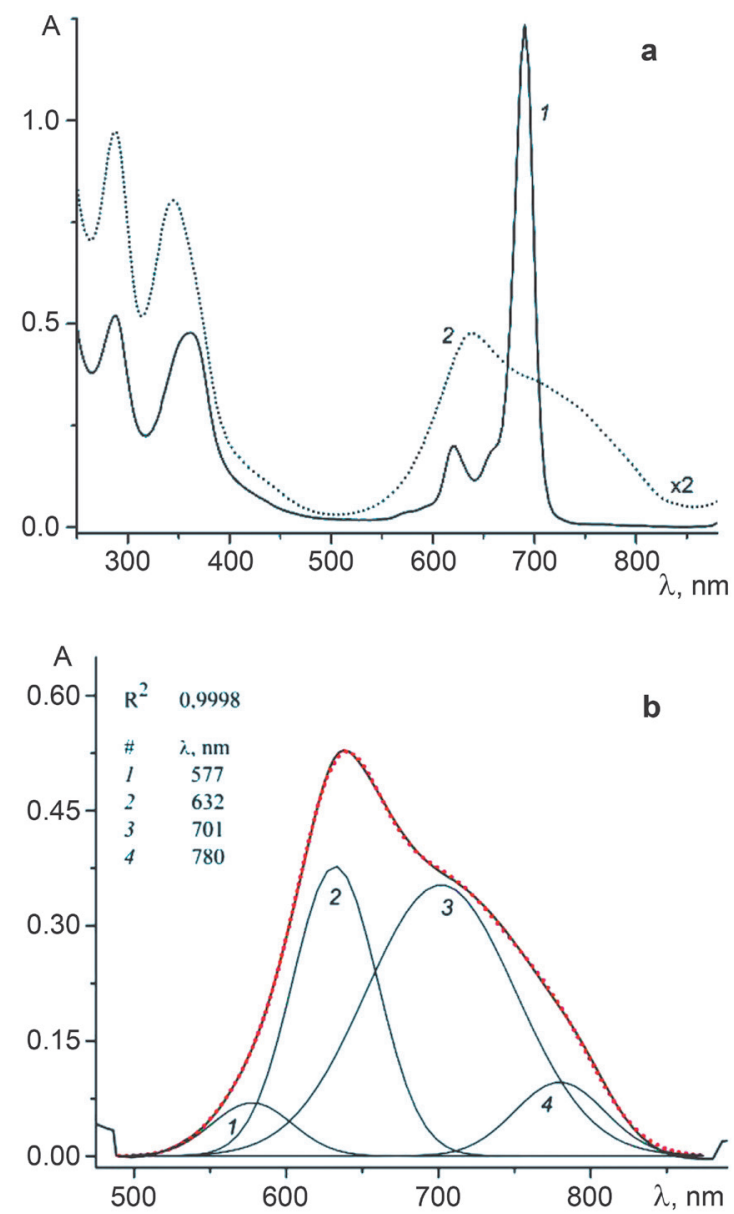

Figure 2. (a) Absorption spectra of $\mathrm{Mgcr}_{8} \mathrm{Pc}$ in dichloromethane (curve 1) and in phosphate buffer (curve 2); (b) Fragment of the $\mathrm{Mgcr}_{8} \mathrm{Pc}$ spectrum in EMEM medium and its deconvolution into Gaussian functions; the red line is the envelope of the deconvolution contours, and the thin black solid lines are Gaussian contours.

The absorption spectra of $\mathrm{Mgcr}_{8} \mathrm{Pc}$ in SDS/water and SDS/PBS are also markedly different ([SDS] $\geq \mathrm{cmc}$ in both systems): Pc as monomer in the former case (Figure 4 , spectrum 1 and see also $\left.{ }^{[15]}\right)$, no clearly pronounced maximum, a larger half-width of the $Q$-band, and lower $\varepsilon$ value in the latter case (Figure 4, spectrum 2).

Thus, the present in PBS of the $\mathrm{K}^{+}$ions (see Experimental) whose diameter (2.66 $\AA$ ) significantly exceeds the diameter of the cavity in 15-crown-5 (1.7-2.2 $\AA),{ }^{[10,11]}$ facilitates the cation-induced aggregation of $\mathrm{Mgcr}_{8} \mathrm{Pc}$ even in the presence of anionic surfactants such as sodium deoxycholate and sodium dodecyl sulfate. In all cases, spectral features obtained appear in the presence of the $\mathrm{K}^{+}$ions (see Figures 3 and 4). It was previously shown ${ }^{[20]}$ that the $\mathrm{K}^{+}$ions in the $\mathrm{KCl}$ aqueous solution lead to the formation of stable charged forms (dimers) of octa-crown metal phthalocyanines.

\section{Photoexcitation of $\mathrm{Mgcr}_{8} \mathrm{Pc} / \mathrm{SDC} / \mathrm{PBS}$ Solutions}

Figure 5a presents the normalized fluorescence and excitation spectra for $\mathrm{Mgcr}_{8} \mathrm{Pc} / \mathrm{PBS} / \mathrm{SDC}$ solution. The excitation spectrum in Figure 5a (curve 2) corresponds
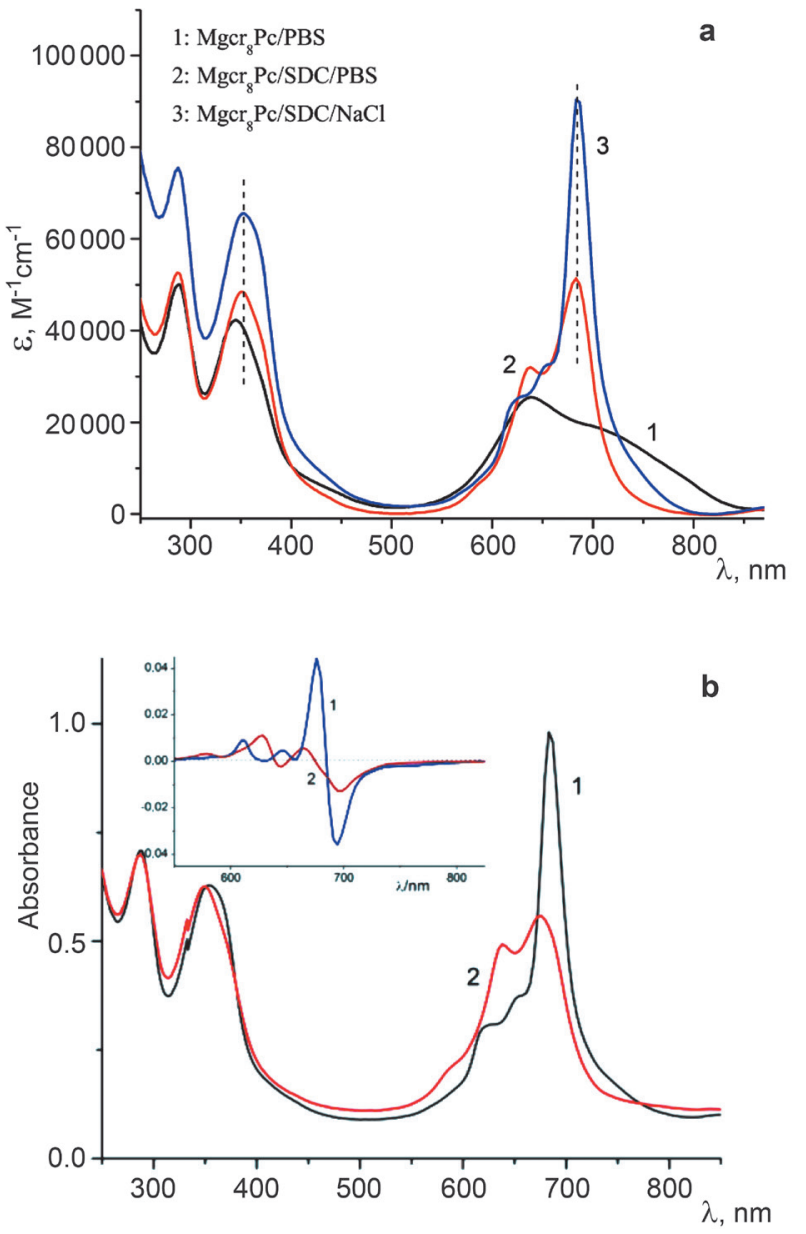

Figure 3. (a) Absorption spectra of $\mathrm{Mgcr}_{8} \mathrm{Pc} / \mathrm{PBS}$, $\mathrm{Mgcr}_{8} \mathrm{Pc} / \mathrm{SDC} / \mathrm{PBS}$ and $\mathrm{Mgcr}_{8} \mathrm{Pc} / \mathrm{SDC} / \mathrm{NaCl}$ solutions (1, 2 and 3, respectively); $\left[\mathrm{Mgcr}_{8} \mathrm{Pc}\right]=9.3 \cdot 10^{-6} \mathrm{M}$, $[\mathrm{SDC}]=0.016 \mathrm{M}$. (b) Salt effect on absorption spectra of $\mathrm{Mgcr}_{8} \mathrm{Pc}$ in micro-heterogeneous systems: $\mathrm{SDC} / \mathrm{NaCl}([\mathrm{NaCl}]=0.139 \mathrm{M}+0.025 \mathrm{M}$; spectrum 1$)$ and $\mathrm{SDC} / \mathrm{NaCl} / \mathrm{KCl}([\mathrm{NaCl}]=0.139 \mathrm{M}$ and $[\mathrm{KCl}]=0.022 \mathrm{M}$; spectrum 2). Insert: first derivatives of spectral bands 1 and 2 , respectively.

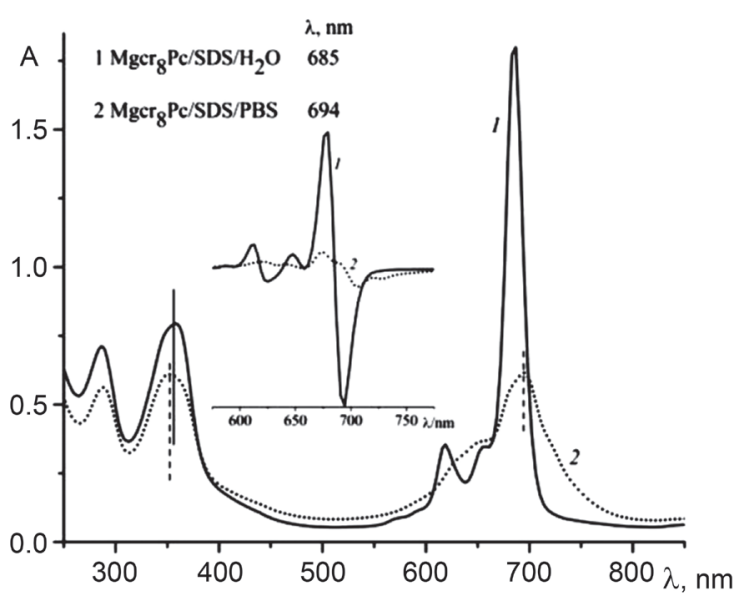

Figure 4. Absorption spectra of $\mathrm{Mgcr}_{8} \mathrm{Pc}$ in SDS/water (curve 1) and SDS/PBS (curve 2) solutions. Insert: first derivatives of spectral bands 1 and 2, respectively. 

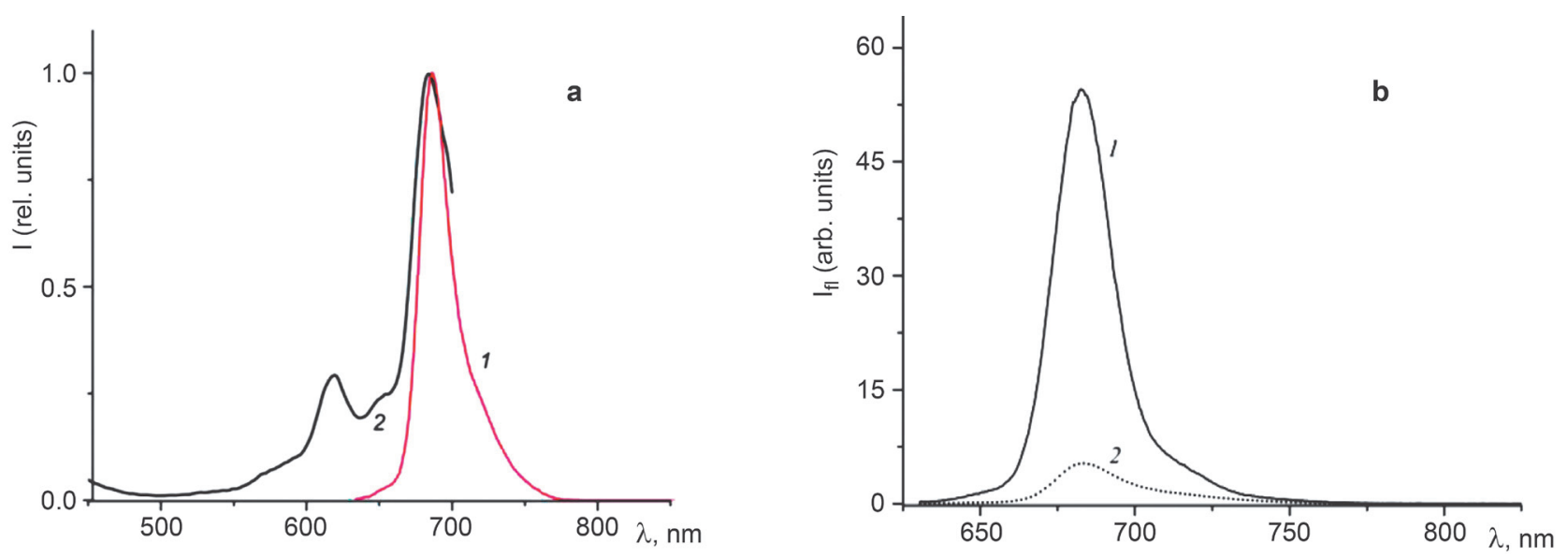

Figure 5. $\mathrm{Mgcr}_{8} \mathrm{Pc} / \mathrm{SDC} / \mathrm{PBS}$ solution: (a) fluorescence spectrum as excited at $\lambda_{\text {ex }}=614 \mathrm{~nm}$ (curve 1) and excitation spectrum as taken at $\lambda_{\mathrm{em}}=704 \mathrm{~nm}$ (curve 2); (b) relative fluorescence intensities for $\mathrm{Mgcr}_{8} \mathrm{Pc} / \mathrm{SDC} / \mathrm{NaCl}$ (curve 1) and $\mathrm{Mgcr}{ }_{8} \mathrm{Pc} / \mathrm{SDC} / \mathrm{PBS}$ (curve 2) systems.

to the absorption spectra of the $\mathrm{Mgcr}_{8} \mathrm{Pc}$ monomer in dichloromethane (Figure 2a, curve 1) or in the SDS/ $\mathrm{H}_{2} \mathrm{O}$ medium at $[\mathrm{SDS}] \geq \mathrm{cmc}$ (critical micelle concentration), but strongly differs from the absorption spectrum of $\mathrm{Mgcr}_{8} \mathrm{Pc}$ in $\mathrm{PBS} / \mathrm{SDC}$ solution $([\mathrm{SDC}] \geq \mathrm{cmc}]$ ) (see Figure 4, curve 1 and Figure 3, curve 2 , respectively). This behavior is also characteristic of the $\mathrm{Mgcr}_{8} \mathrm{Pc}$ in the SDS/PBS microheterogeneous system.

Relative fluorescence intensities for $\mathrm{Mgcr}_{8} \mathrm{Pc} / \mathrm{PBS} /$ $\mathrm{SDC}$ and $\mathrm{Mgcr}_{8} \mathrm{Pc} / \mathrm{NaCl} / \mathrm{SDC}$ solutions are shown in Figure $5 \mathrm{~b}$. It is seen that the fluorescence intensity of $\mathrm{Mgcr}_{8} \mathrm{Pc} /$ $\mathrm{NaCl} / \mathrm{SDC}$ is stronger than that of $\mathrm{Mgcr}_{8} \mathrm{Pc} / \mathrm{PBS} / \mathrm{SDC}$. This may be due to a higher degree of the $\mathrm{Mgcr}_{8} \mathrm{Pc}$ aggregation in the PBS/SDC medium (see also Figure 3).

Thus, the observation of the $\mathrm{Mgcr}_{8} \mathrm{Pc}$ fluorescence in the microheterogeneous PBS/SDC and PBS/SDS systems confirms (i) the presence of a certain concentration of monomeric Pc and (ii) the absence of fluorescence quenching as a result of screening $\mathrm{Mgcr}_{8} \mathrm{Pc}$ molecules from the aqueous medium by SDC aggregates (micelles) or SDS micelles, since the fluorescence of $H$-dimers and larger Pc aggregates is reportedly quenched. ${ }^{[21]}$

At normal conditions, $\mathrm{Mgcr}_{8} \mathrm{Pc}$ solutions in water and phosphate buffer remain stable for a long time. When $\mathrm{Mgcr}_{8} \mathrm{Pc} / \mathrm{SDC} / \mathrm{PBS}$ samples were subjected to diffuse illumination for a long time, the optical density of the $B$ and $Q$-bands in the absorption spectrum decreased smoothly, which was accompanied by the appearance of new bands at shorter wavelengths, just as in case of $\mathrm{Mgcr}_{8} \mathrm{Pc} / \mathrm{SDC} /$ $\mathrm{NaCl}$ (see Figure 6). In other words, we observe the true photobleaching of Pc solution typical to Pc monomers. According to ${ }^{[22]}$ the photodestruction of Pc yields respective phthalimides, as shown also for Pc with four annulated crown fragments in the NMR spectra ${ }^{[23]}$ and for Pc with eight methyl phosphonate groups. ${ }^{[24]}$

\section{Cytotoxicity of $\mathrm{Mgcr}_{8} \mathrm{Pc}$ and Its Accumulation/ Localization in HeLa Cells}

Metal phthalocyanines containing crown ether solubilize in microheterogeneous SDC-based media largely in the form of monomers in the presence of physiological concentrations of sodium chloride (see Figure 3 and also $^{[19]}$ ), but our control experiments and literature data have revealed that SDC is quite toxic not only for HeLa but also for some other cells. ${ }^{[25-27]}$ This circumstance impeded a correct exploration of the cytotoxicity of the fluorescing $\mathrm{Mgcr}_{8} \mathrm{Pc} / \mathrm{SDC} /$ PBS system.

At this stage, we investigated as a result the toxicity of $\mathrm{Mgcr}_{8} \mathrm{Pc}$ itself and also its ability to penetrate and to accumulate in HeLa cells.

The state of the $\mathrm{Mgcr}_{8} \mathrm{Pc}$ in the cells and its possible changes in comparison with Pc in EMEM medium (see above) are of current interest. Based on the known data on the supramolecular organization of $\mathrm{Mgcr}_{8} \mathrm{Pc}$ in microheterogeneous media ${ }^{[28]}$ and due to non-covalent interactions of various types (see work ${ }^{[29]}$ and references therein), certain modifications of the Pc state in cells could well be expected.

\section{Cytotoxicity of $\mathrm{Mgcr}_{8} \mathrm{Pc}$}

Figure 7 shows the results of MTT tests of cytotoxicity of $\mathrm{Mgcr}_{8} \mathrm{Pc}$ toward tumor cells HeLa. The data obtained

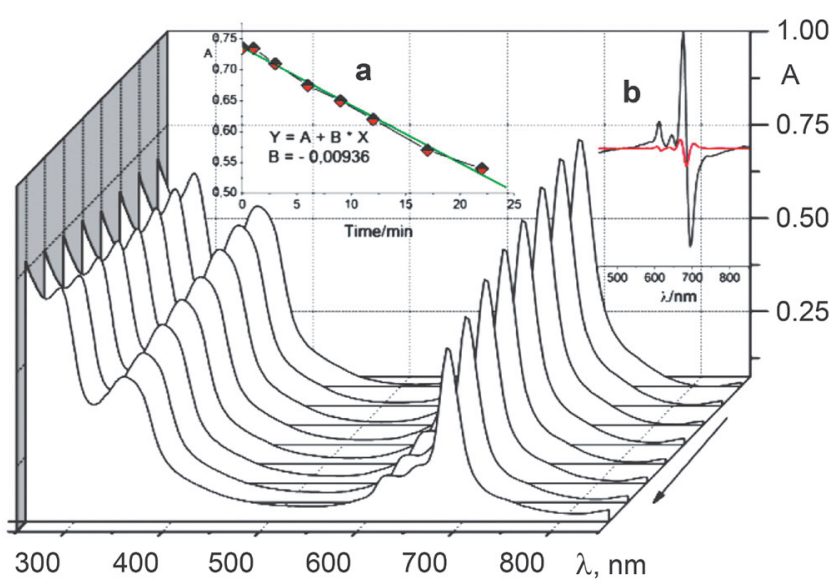

Figure 6. Photobleaching of $\mathrm{Mgcr}_{8} \mathrm{Pc}$ in microheterogeneous system $\mathrm{SDC} / \mathrm{NaCl}, \lambda_{\text {ex }}=578 \mathrm{~nm}$. Inserts: (a) $\mathrm{A}_{683} v$ s. time; (b) first and second derivatives of the initial $\mathrm{Mgcr}_{8} \mathrm{Pc}$ spectrum (before irradiation). $\left[\mathrm{Mgcr}_{8} \mathrm{Pc}\right]=7.4 \cdot 10^{-6} \mathrm{M},[\mathrm{SDC}]=0.016 \mathrm{M}$, $[\mathrm{NaCl}]=0.1016 \mathrm{M}$. 
allow us to state that the cell proliferation is supressed in a dose-dependent mode.

It should be also noted that the washing of cells with PBS or its absence before dye applying do not have a determining influence on the staining MTT value determined: the $\mathrm{IC}_{50}$ concentrations were found to have a value of 8.48 and $9.58 \mu \mathrm{M}$, respectively.

\section{Accumulation of $\mathrm{Mgcr}_{8} \mathrm{Pc}$ in HeLa Cells}

The intracellular content and distribution of the test compound was evaluated by fluorescence microscopy. Fig-

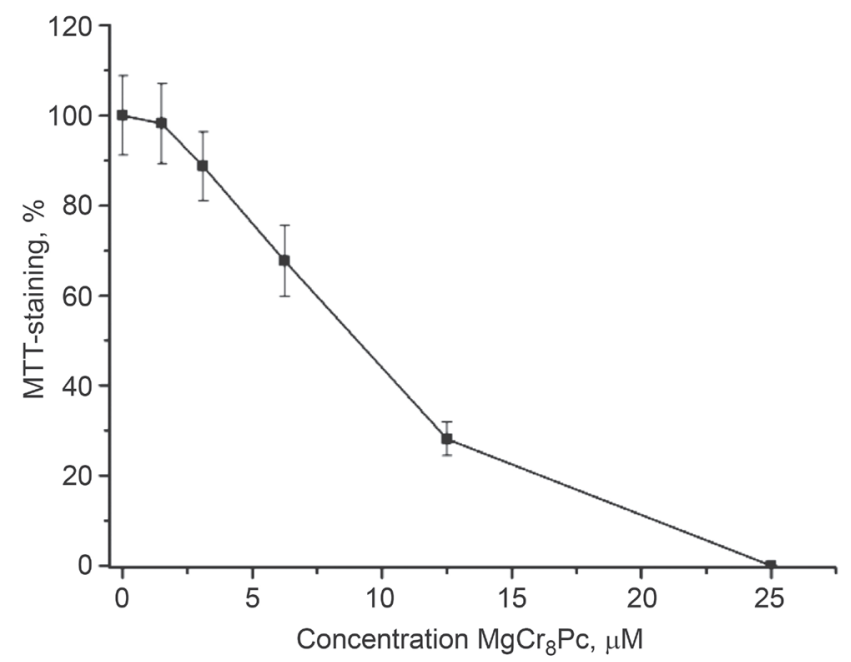

Figure 7. Cytotoxicity of $\mathrm{Mgcr}_{8} \mathrm{Pc} v s$. tumor cells HeLa; before applying the MTT dye the sample was washed with PBS. ure 8 illustrates the $\mathrm{Mgcr}_{8} \mathrm{Pc}$ accumulation and localization in HeLa cells. The phase contrast images show (Figure 8-2A) that as a result of the incubation with $\left[\mathrm{Mgcr}_{8} \mathrm{Pc}\right]=5 \mu \mathrm{M}$ for $3 \mathrm{~h}$ the cell morphology remained practically unchanged. The distribution of Pc over the cells is non-uniform as evidenced by brightly colored granules in Figure 8-2C. . $^{[30]}$ The incubation of cells with $\mathrm{Mgcr}_{8} \mathrm{Pc}$ for $24 \mathrm{~h}$ noticeably increases the signal from $\mathrm{Mgcr}_{8} \mathrm{Pc}$ in the cytoplasm of cells (Figure 8-3C).

The results on the accumulation of $\mathrm{Mgcr}_{8} \mathrm{Pc}$ in nonfixed HeLa cells also confirm that $\mathrm{Mgcr}_{8} \mathrm{Pc}$ absorbs in cells at $\left[\mathrm{Mgcr}_{8} \mathrm{Pc}\right]=5 \mu \mathrm{M}$ for $24 \mathrm{~h}$ (Figure 9) and localizes predominantly in the cytoplasm of the latter.

Thus, $\mathrm{Mgcr}_{8} \mathrm{Pc}$ is soluble in water, PBS, and culture medium EMEM, where it is present mainly in an aggregated state. Addition of sodium deoxycholate promotes the partial Pc monomerization and appearance of fluorescent species, respectively. Treatment of HeLa cells with $\mathrm{Mgcr}_{8} \mathrm{Pc} /$ PBS solution in culture medium led to the penetration/ accumulation of Pc in the cells. Toxicity of $\mathrm{Mgcr}_{8} \mathrm{Pc}(8.48$ $\mu \mathrm{M})$ toward HeLa is higher as compared to that of some substituted Pc of Mg, Zn, metal-free Pc and hydroxyaluminum trisulfophthalocyanine (Photosens, Russia). So, the latter adsorbed on polymer nanoparticles shows low cytotoxicity toward HeLa cells for [Pc] $<11.2 \mu \mathrm{g} / \mathrm{mL}(12.74 \mu \mathrm{M}) \cdot{ }^{[31]}$ For zinc 9,10,16,17,23,24-hexa(4'-tert-butylphenoxy)-2-[2'-(4"carboxyphenyl)ethynyl]phthalocyanine and HeLa cells, $\mathrm{IC}_{50}$ equals to $21.44 \mu \mathrm{M}$; ${ }^{[32]}$ for other derivatives of $\mathrm{MgPcs}$, $\mathrm{ZnPcs}$, and $2 \mathrm{HPcs}, \mathrm{IC}_{50}>100 \mu \mathrm{M}\left(\mathrm{see}^{[33,34]}\right)$.

The fluorescence of $\mathrm{Mgcr}_{8} \mathrm{Pc}$ molecules located in the fixed and non-fixed cells HeLa indicates that Pc is present in them in the state really strongly differing from that in culture medium. The micrographs of fluorescence

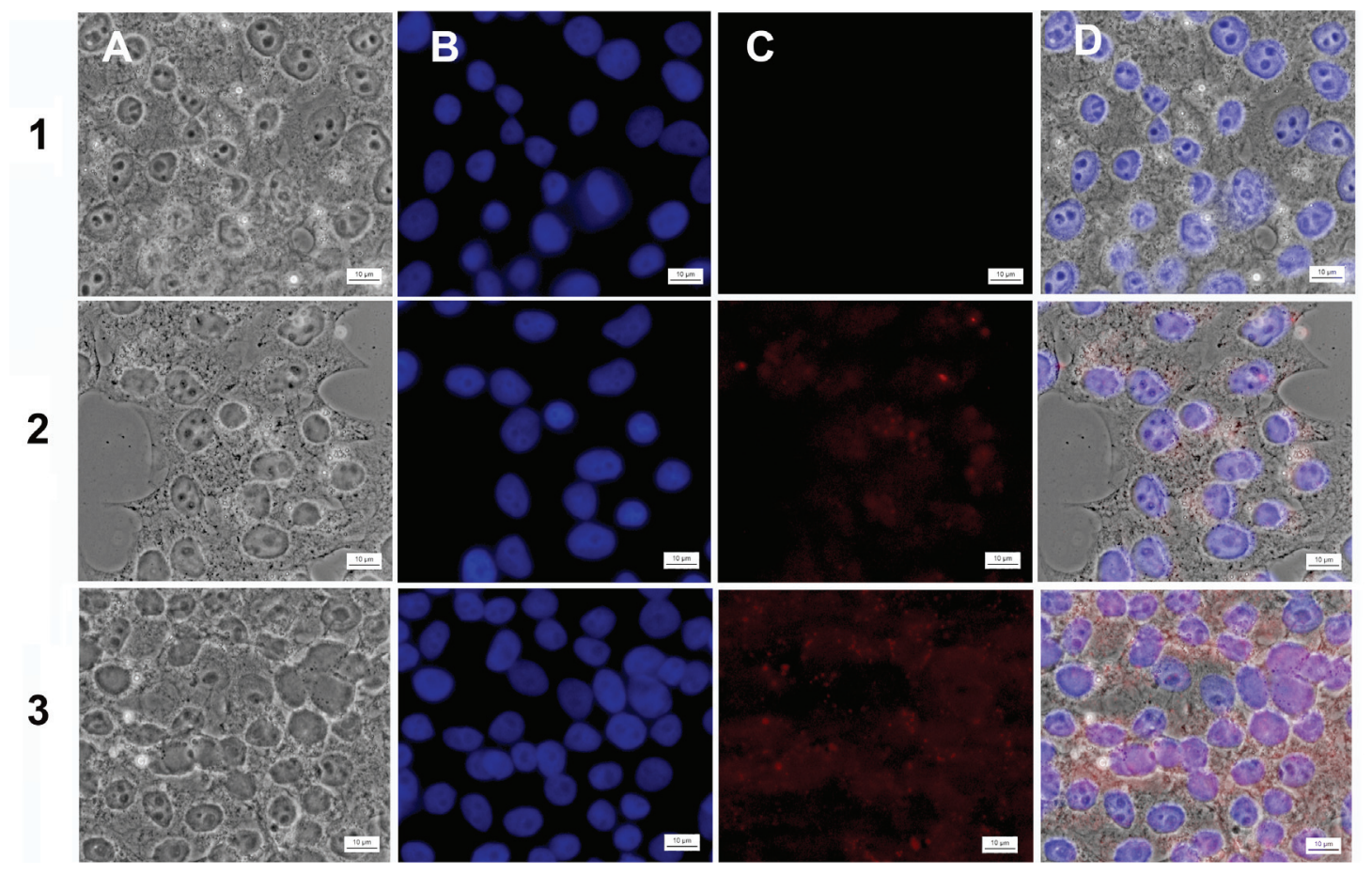

Figure 8. Localization of $\mathrm{Mgcr}_{8} \mathrm{Pc}$ in HeLa cells. Lines: $1 \mathrm{~A}-\mathrm{D}$ unprocessed cells, $2 \mathrm{~A}-\mathrm{D}$ cells processed with $\left[\mathrm{Mgcr}_{8} \mathrm{Pc}\right]=5 \mu \mathrm{M}$ for $3 \mathrm{~h}$, $3 \mathrm{~A}-\mathrm{D}$ cells processed with $\left[\mathrm{Mgcr}_{8} \mathrm{Pc}\right]=5 \mu \mathrm{M}$ for $24 \mathrm{~h}$. Columns: A1-3 phase contrast, B1-3 nuclei stained with DAPI, C1-3 fluorescence of $\mathrm{Mgcr}_{8} \mathrm{Pc}$ in the cells, D1-3 merger. Scale bar $10 \mu \mathrm{m}$. 


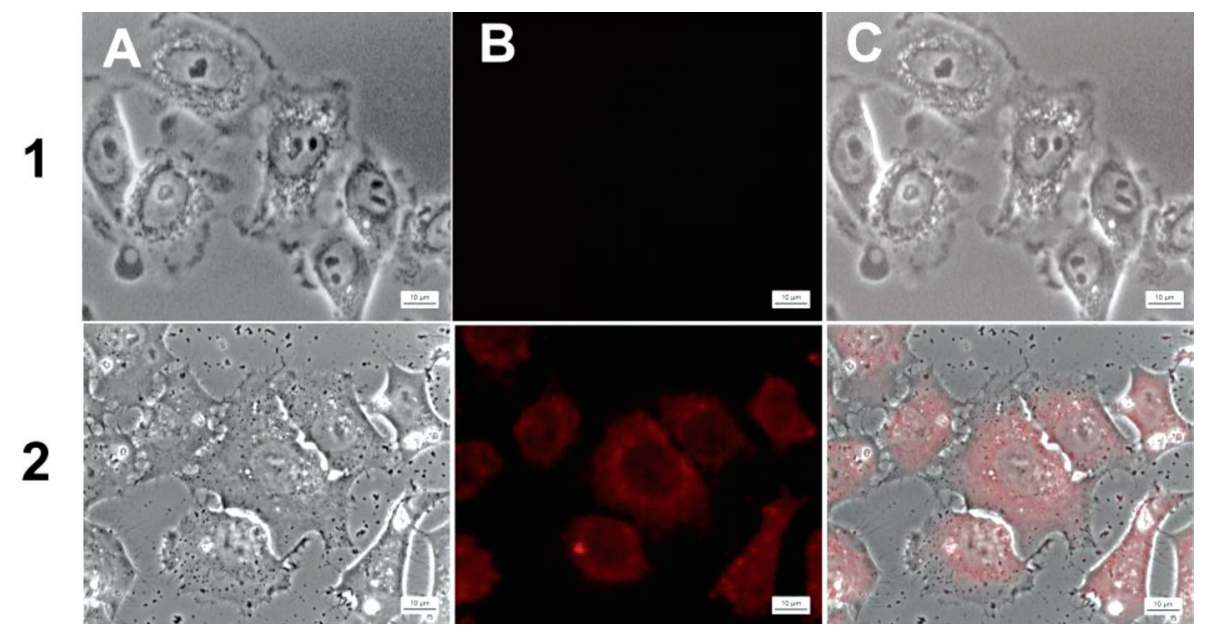

Figure 9. Localization of $\mathrm{Mgcr}_{8} \mathrm{Pc}$ in HeLa cells (without fixation). Lines: $1 \mathrm{~A}-\mathrm{C}$ unprocessed cells, $2 \mathrm{~A}-\mathrm{C}$ cells processed with $\left[\mathrm{Mgcr}_{8} \mathrm{Pc}\right]=5 \mu \mathrm{M}$ for $24 \mathrm{~h}$. Columns: A1-2 phase contrast, B1-2 accumulation/localization of $\mathrm{Mgcr}_{8} \mathrm{Pc}$ in the cells, C1-3 merger. Scale bar $10 \mu \mathrm{m}$.

microscopy evidence the accumulation and the localization of $\mathrm{Mgcr}_{8} \mathrm{Pc}$ in tumor cells of HeLa. High toxicity of $\mathrm{Mgcr}_{8} \mathrm{Pc}$ may be associated with the disruption of the cellular ion balance due to the presence of eight crown ether groups in the molecule. For instance, a recent review was devoted to crown ethers and some compounds based on them as prospective antitumor agents. ${ }^{[35]}$

\section{Conclusions}

For the first time, magnesium octa[(4'-benzo-15crown-5)oxy]phthalocyanine was explored as a potential PDT agent. The results on the HeLa cells demonstrate that $\mathrm{Mgcr}_{8} \mathrm{Pc}$ accumulates in their intracellular space. Absorption spectroscopy data on the Pc uptake by cells are consistent with the results of fluorescence microscopy. Further studies, including the determination of the $\mathrm{Mgcr}_{8} \mathrm{Pc}$ photocytotoxicity, etc., are in progress.

Acknowledgments. This work was performed in accordance with the state task, state registration: 0089-20-140036, 0089-20-14-0040, and 0090-20-17-0024, and Russian Academy of Sciences (program no. 34). We are also grateful to V.Yu. Gak for taking the fluorescence spectra.

\section{References and Notes}

1. Shaposhnikov G.P., Kulinich V.P., Maizlish V.E. Modified Phthalocyanines and their Structural Analogues (Koifman O.I., Ed.). Moscow: Krasand, 2012. 480 p. (in Russ.) [Шапошников Г.П., Кулинич В.П., Майзлиш В.Е. Модифицированные фталоцианины и их структурные аналоги (Койфман О.И., ред.). М.: Красанд, 2012. 480 с.].

2. van Nostrum C.F., Nolte R.J.M. Chem. Commun. 1996, 2385-2392.

3. Fan W., Huang P., Chen X. Chem. Soc. Rev. 2016, 45, 6488-6519.

4. Wang S., Gao R., Zhou F., Selke M. J. Mater. Chem. 2004, 14, 487-493.
5. Dabrowski J.M., Arnaut L.G. Photochem. Photobiol. Sci. 2015, 14, 1765-1780.

6. Nyokong T. Pure Appl. Chem. 2011, 83, 1763-1779.

7. Lukyanets E.A. J. Porphyrins Phthalocyanines 1999, 3, 424-432.

8. Dai L., Yu Y., Luo Z., Li M., Chen W., Shen X., Chen F., Sun Q., Zhang Q., Gu H., Cai K. Biomaterials 2016, 104, 1-17.

9. Yakubovskaya R.I., Plyutinskaya A.D., Lukyanets E.A. Ross. Bioterapevt. Zh. 2014, 13, 65-72.

10. Steed J.W., Atwood J.A. Supramolecular Chemistry. Chichester: John Wiley \& Son, Ltd, 2000.

11. Tsivadze A.Yu. Usp. Khim. 2004, 73, 6-25 [Russ. Chem. Rev. 2004, 73, 5-23].

12. Logacheva N.M., Baulin V.E., Tsivadze A.Yu., Basova T.V., Sheludyakova L.A. Izv. Akad. Nauk. Ser. Khim. 2008, 1439-1447 [Russ. Chem. Bull. 2008, 1467-1476].

13. Ahsen V., Yilmazer E., Ertas M., Bekaroğlu Ö.J. J. Chem. Soc., Dalton Trans. 1988, 401-406.

14. Gorbunova Y.G., Martynov A.G., Tsivadze A.Yu. Crown-Substituted Phthalocyanines: From Synthesis Towards Materials. In: Handbook of Porphyrin Science, Vol. 24 (Kadish K.M., Smith K.M., Guilard R., Eds.) World Scientific Publishing: 2012, Chapter 113. p. 271-388.

15. Goldshleger N.F., Chernyak A.V., Kalashnikova I.P., Baulin V.E., Tsivadze A.Yu. Russ. J. Gen. Chem. 2012, 82, 927-935.

16. Mosmann T. J. Immunol. Methods 1983, 65, 55-63.

17. Chou C., Talalay P. Adv. Enzyme Regul. 1984, 22, 27-55.

18. Chou T.C. Pharmacol. Rev. 2006, 58, 621-681.

19. Gol'dshleger. N.F., Lobach A.S., Gak V.Yu., Kalashnikova I.P., Baulin V.E., Tsivadze A.Yu. Prot. Met. Phys. Chem. Surf. 2014, 50, 599-607.

20. Ovsyannikova E.V., Goldshleger N.F., Kurochkina N.M., Baulin V.E., Tsivadze A.Yu., Alpatova N.M. Macroheterocycles 2010, 3, 125-133.

21. Kasha M., Rawis H.R., El-Bayoumi M.A. Pure Appl. Chem. 1965, 11, 371-392.

22. Slota R., Dyrda G. Inorg. Chem. 2003, 42, 5743-5750.

23. Lapkina L.A., Gorbunova Y.G., Gil D.O., Ivanov V.K., Konstantinov N.Yu., Tsivadze A.Yu. J. Porphyrins Phthalocyanines 2013, 17, 564-572.

24. Komissarov A.N., Makarov D.A., Yuzhakova O.A., Savvina L.P., Kuznetsova N.A., Kaliya O.L., Lukyanets E.A., Negrimovsky V.M. Macroheterocycles 2012, 5, 169-174. 
25. Krishnamurthy K., Wang G., Rokhfeld D., Bieberich E. Breast Cancer Res. 2008, 10, R106.

26. Schlottmann K., Wachs F.-P., Krieg R.C., Kullmann F., Schölmerich J., Rogler G. Cancer Res. 2000, 60, 4270-4276.

27. Bernstein C., Holubec H., Bhattacharyya A.K., Nguyen H., Payne C.M., Zaitlin B., Bernstein H. Arch. Toxicol. 2011, 85, 863-871.

28. Gol'dshleger N.F., Baulin V.E., Tsivadze A.Yu. Prot. Met. Phys. Chem. Surf. 2014, 50, 135-172.

29. Osterloh J., Vicente M.G.H. J. Porphyrins Phthalocyanines 2002, 6, 305-324.

30. Treatment of $\mathrm{Mgcr}_{8} \mathrm{Pc}$ with a $4 \%$ paraformaldehyde solution in PBS or Triton X100 at their concentrations and ratios used in the fixation and permeabilization steps did not result in spectral changes indicating the monomerization of Pc.
31. Khanadeev V., Khlebtsov B., Packirisamy G., Khlebtsov N., Proc. SPIE 2017, 10336.

32. Yurt F., Ocakoglu K., Ince M., Colak S.G., Er O., Soylu H.M., Gunduz C., Avci C.B., Kurt C.C. Chem. Biol. Drug Des. 2018, 91, 789-796.

33. $[1,4,8,11,15,18,22,25$-Octakis[(2-(triethylammonio)ethyl)sulfanyl]phthalocyaninato]magnesium(II) octaiodide; $[1,4,8$, $11,15,18,22,25$-octakis[(2-(triethylammonio)ethyl)sulfanyl]phthalocyaninato]zinc(II) octaiodide; $\quad[1,4,8,11,15,18$, 22,25-octakis[(2-(triethylammonio)ethyl)sulfanyl]phthalocyanine octaiodide (MgPcs, ZnPcs and 2HPcs, respectively).

34. Manilova B., Binder S., Malina L., Jiravova J., Langova K., Koralova H. Anticancer Res. 2015, 35, 3943-3952.

35. Kralj M., Tušek-Božić L., Frkanec L. ChemMedChem. 2008, 3, 1478-1492. 